\title{
Evaluation of thyroid function and autoimmunity in HIV-infected women
}

\author{
Avaliação da função tireoidiana e autoimunidade \\ em mulheres infectadas pelo HIV
}

Leiliane Gonçalves de Carvalho', Patrícia de Fátima dos Santos Teixeira',2, Ana Luiza Brandão Galotti Panico', Marcela Vaisberg Cohen', Maria Fernanda Miguens Castelar Pinheiro ${ }^{3}$, Paulo Feijó Barroso ${ }^{1,4}$, Mário Vaisman ${ }^{1,2}$

\author{
1 Faculdade de Medicina, \\ Universidade Federal do \\ Rio de Janeiro (UFRJ), \\ Rio de Janeiro, RJ, Brazil \\ ${ }^{2}$ Hospital Universitário \\ Clementino Fraga Filho (HUCFF), \\ UFRJ, Endocrinologia, Rio \\ de Janeiro, RJ, Brazil \\ ${ }^{3}$ Sérgio Franco Medicina \\ Diagnóstica, Rio de \\ Janeiro, RJ, Brazil \\ ${ }^{4} \mathrm{HUCFF/UFRJ,} \mathrm{Doenças}$ \\ Infecto-Parasitárias (DIP) \\ Rio de Janeiro, RJ, Brazil
}

Correspondence to: Leiliane Gonçalves Carvalho leilianegc@globo.com

Received on Dec/27/2013 Accepted on Jan/9/2014
A lthough we appreciated your comments, we really did not find a statistically significant relationship between the presence of autoantibodies (autoimmune disease) in patients infected by HIV in use of HAART (1).

It is worthwhile remembering that there are many autoantibodies ("anti-cardiolipin, anti-beta2 GPI, anti-DNA, anti-small nuclear ribonucleoproteins (snRNP), anti-thyroglobulin, anti-thyroid peroxidase, anti-myosin, and anti-erythropoietin antibodies") that may be seen in patients with HIV infection, and there are some mechanisms to explain that, but the relation with the use of HAART has not been demonstrated (2-4).

There are some cases reported of Graves' disease in patients with HIV infection, but the relationship with the use of HAART was not demonstrated $(3,5)$.

We are thankful for your observations, though, as it is very important to have opinions about the same subject.

Disclosure: no potential conflict of interest relevant to this article was reported.

\section{REFERENCES}

1. Carvalho LG, Teixeira PF, Panico AL, Cohen MV, Pinheiro MF, Barroso PF, et al. Evaluation of thyroid function and autoimmunity in HIV-infected women. Arq Bras Endocrinol Metabol. 2013;57(6):450-6.

2. Zandman-Goddard G, ShoenfeldY. HIV and autoimmunity. Autoimmun Rev. 2002;1(6):329-37.

3. Sheikh V, Dersimonian R, Richterman AG, Porter BO, Natarajan V, Burbelo PD, et al. Graves' disease as immune reconstitution disease in HIV-positive patients is associated with naive and primary thymic emigrant CD4+T-cell recovery. AIDS. 2014;28(1):31-9.

4. Chen F, Day SL, Metcalfe RA, Sethi G, Kapembwa MS, Brook MG, et al. Characteristics of autoimmune thyroid disease occurring as a late complication of immune reconstitution in patients with advanced human immunodeficiency virus (HIV) disease. Medicine (Baltimore). 2005;84:98-106.

5. Crum NF, Ganesan A, Johns ST, Wallace MR. Graves' disease: an increasingly recognized immune reconstitution syndrome. AIDS. 2006;20(3):466-9. 